\title{
The Franchising Decision: The Perspective Of The Franchisee In The Hospitality Industry
}

\author{
Ramon Diaz-Bernardo, Instituto de Empresa Business School, Spain
}

\begin{abstract}
Franchising is a major trend in the hotel industry. Despite the fact that almost two-thirds of branded hotels in the U.S. are franchised, there is a lack of empirical research on franchising in the hospitality industry. In this article, I reviewed one of the most relevant lines of research in franchising literature, usually referred as creating franchising systems, and we have concentrated on analyzing the reasons and motivations to use franchising from franchisee perspective within the hospitality industry. The paper identifies the main reasons for choosing franchising for franchisees, explores what are the most valued characteristics of franchising, and gives some guidelines on how to make the franchising offer more appealing to potential franchisees in the hotel industry.
\end{abstract}

Keywords: Franchising, Hotels, Franchisor, Franchisee

\section{INTRODUCTION}

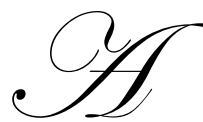

franchise system is a collaboration agreement between two independent business partners, the franchisor and the franchisee, whereby the franchisor allows the franchisee the right to use his brand name, products and services, and specific know-how in exchange for direct or indirect payments to the franchisor by the franchisee. In other words, the franchise system consists of multiple organizations that are legally independent, economically interdependent, and operationallyindistinguishable to consumers (Parsa 1996).

The success of the franchise system is reflected in its spectacular growth figures. In the U.S., where the franchising system began in the early $20^{\text {th }}$ century, there are over 3,000 companies involved in franchising, accounting for over $10 \%$ of GDP and an estimated $30 \%$ of retail sales.

In the hotel industry, the franchising system is also constantly growing. According to Mintel Marketing Intelligence's 2005 International Hotel Industry Report, 67\% of U.S. room capacity is branded, mainly through franchise contracts. Almost all the big U.S. hotel chains are involved in franchising. Eighteen of the top 20 U.S. hotel brands use franchising, so it has become a hot topic of interest in the hotel industry. The situation is different in Europe where the franchising system is less popular and the hotel chains still prefer to grow via leasing or management contracts instead of franchising.

When inquiring about the different behavior of the European and the U.S. hotel markets concerning franchising, our two European experts expressed similar opinions. Mr. Jordi Frigola, Senior Vice President of Jones Lang LaSalle in Europe, explained, "In Europe the level of concentration and branding is very low compared to the U.S. Most of the European hotel chains prefer the leasing contracts and the investors prefer a lease contract with no risk rather than hands-on franchising contracts." In a similar vein, Mr. Bernardo Cabot, Director of Expansion's European Division of Sol Melia, added, "There are three potential barriers to the development of franchising in the European hotel industry: 1) a lack of potential franchisees with both the necessary skills and the financial resources needed, 2) a great concern about the quality standards of the potential franchisees and how to enforce the chain's quality standards in the franchisee's property, and 3) litigation and other legal issues involved in the franchise contract." 
In parallel with the rapid expansion of franchising, there is a growing interest among academics and practitioners in studying the franchise system. The literature on franchising has followed three major lines of research: 1) franchising and society, 2) creating a franchise system, and 3) managing a franchise system. In this paper, we will concentrate on analyzing the line of research known as creating franchise systems and, specifically, we will concentrate on franchising from the perspective of the franchisee. We will do so by reviewing the relevant literature on the subject and by comparing what the theory says with the opinions of our panel of experts, as well as with the empirical information collected from public sources of information regarding the hotel industry.

\section{THE DECISION TO BE A FRANCHISEE: A THEORY OF FRANCHISE DEMAND AND ITS APPLICATION IN THE HOTEL INDUSTRY}

As described by Fulop and Forward (1997), a lot of theoretical and empirical research has been devoted to explain why firms franchise. However, few studies have aimed to explore the importance and the advantages of the franchise system from the perspective of the franchisee; that is, the entrepreneur choice of franchise vs. independent ownership - a theory of franchise demand.

Given the relevance of franchising to the development of businesses, it is interesting to learn why so little attention has been paid to the decision of would-be entrepreneurs to eschew the independent operation and become franchisees. The issue of franchisee motives, though widely recognized and frequently discussed by franchisors, still remains largely unexplored in empirical research terms.

From a managerial point of view, a better understanding of the franchisee's motivation will provide some interesting insights to franchisors as to how to position their offer in the franchise market. Franchising is not only an organizational system, it is also a market where franchisors compete for the best potential franchisees. Therefore, knowing the motivations of the franchisees and why they chose this alternative, as well as the most valued characteristics of the system, would be important to design the franchise offer. Mr. Joe Lavin, ex-Senior Vice President for Marriott and Choice Hotels, describes 'franchising market' in the hotel industry as 'a competition between hotel brands to get the best franchisees and locations, but probably concentrated from the upper mid-scale category and down'.

Research addressing the issue of motives attracting entrepreneurs to become franchisees is found in the work of Izraeli (1972), Knight (1986), Peterson \& Dant (1990), Whitane (1991), and Stanworth and Kaufmann (1996). According to these authors, the reasons to become a franchisee can be grouped into two main categories: 1) the advantages of the franchise option over starting one's own independent business and 2) the advantages of the franchising option over being an employee. Izraeli (1972) provided a list of 17 motives for choosing the franchise option, defined as the franchising advantages. Knight (1986) developed a scale to test the advantages of the franchise option compared to being a salaried employee and an independent operation. With a sample of Canadian franchisees in a variety of industries, he found that using an established brand name was the principal advantage of the franchise option. Peterson and Dant (1990) grouped the 17 motivations developed by Izraeli (1972) into seven categories: 1) lower development costs, 2) established name, 3) lower operating costs, 4) less involvement, 5) greater independence, 6) better investment, and 7) training. These authors, using a sample of U.S. service industry franchisees, found that having an established brand name was an important motivation, but ranked first were 'training by the franchisor' and 'greater independence'. Whitane (1991), with a sample of U.S. franchisees from the fast food services and merchandise sectors, explored the motivation for starting a franchise as opposed to an independent business. The results indicated that having a proven business format was the most influential reason for the franchisee. Finally, Stanworth and Kaufmann (1996) worked with a sample of U.S. and UK potential franchisees focusing on the franchisees' motivations in the initial stage. Their results show that the main reasons for the potential franchisees are having a proven business system, independence, and trade name.

With a sample of Spanish franchisees, the author conducted an empirical research on the motivations to choose the franchising option. The eight constructs used to evaluate the perceived advantages of franchising over an independent business were: 1) lower risk, 2) trade name, 3) lower developing costs, 4) help in financing, 5) training, 6) less operating costs, 7) less involvement, and 8) proven business formula. The three constructs to evaluate the 
perceived advantages of franchising over being an employee were: 1) independence, 2) more money, and 3) prestige.

Our results showed that compared to an independent business, the franchise option has three clear advantages for the franchisees: 1) using an established brand name that attracts customers, 2) working with a proven business format to reduce the chances of failure, and 3) receiving initial and on-going training by the franchisor on how to run the business. On the other hand, two reasons not perceived as advantages of the franchising system or to become a franchisee are less management involvement and ease of obtaining financing. In response to the main reason for choosing the franchise option over being an employee, franchisees clearly stated it is the greater independence associated with having your own business. Franchisees also agreed, to some extent, that franchising has the additional advantages of involving lower risk than an independent business, having lower operating costs, and having lower development costs. Other underlying motivators of the decision to be a franchisee relate to the perception that 1) being a franchisee, you can make more money than if you were an employee and 2) franchising gives you the prestige associated with being an entrepreneur.

Comparing the results of the different published studies, we can infer some new insights into the main reasons for choosing the franchising option. Some previous studies reported nominal data, but we can infer the relative importance of each of the advantages from the frequencies with which different reasons were agreed upon by the respondents. The country in which the research was conducted is another issue of comparison due to the multicultural origin of the studies. We offer a comparison of the reasons to become a franchisee in four countries: United States, Canada, United Kingdom, and Spain.

Table 1: Comparison of Reasons to Become A Franchisee in Different Studies and Countries

\begin{tabular}{|c|l|l|l|c|c|}
\hline & \multicolumn{1}{|c|}{ Kinght (1986) } & \multicolumn{1}{|c|}{ Peterson and Dant (1990) } & \multicolumn{1}{|c|}{ Withane (1991) } & $\begin{array}{c}\text { Stanworth and } \\
\text { Kaufmann (1996) }\end{array}$ & $\begin{array}{c}\text { Diaz-Bernardo } \\
(\mathbf{2 0 0 5})\end{array}$ \\
\hline & \multicolumn{1}{|c|}{ Canada } & \multicolumn{1}{c|}{ U.S.A. } & \multicolumn{1}{|c|}{ U.S.A. } & U.K. & Spain \\
\hline 1 & Brand Name & Training & Proven Business & Proven Business & Brand Name \\
\hline 2 & Job Satisfaction & Brand Name & Lower Risk & Independence & Independence \\
\hline 3 & Greater Independence & Greater Independence & Brand Name & Brand Name & Proven Business \\
\hline 4 & Faster Development & Better Investment & Start-up Support & Lower Risk & Training \\
\hline 5 & Proven Business & Lower Development Costs & On-going Support & On-going Support & Lower Risk \\
\hline
\end{tabular}

Table 1 represents the comparison of results of the different studies. Because each study used a different evaluation methodology of the franchisees' motivations, we report only the rank, not the data corresponding to each reason tested. 'Trade Name' - or 'brand name' - is the most agreed upon advantage of the franchise system in our study and it also ranks first in Knight (1986), second in Peterson \& Dant (1990), and third in Withane (1991) and Stanworth \& Kaufmann (1996). 'Greater independence' associated with being a franchisee versus being an employee was ranked second in our sample, second in the Stanworth \& Kaufmann (1996) study, and third in the Peterson \& Dant (1990) and Knight (1990) studies. 'Using a proven business format' appears third in our study as the reason for buying a franchise, first in both the Withane (1991) and Stanworth \& Kaufmann (1996) studies, fifth in Knight (1986), and fourth in Peterson \& Dant (1990). 'Training' was ranked fourth in our study and is the highest ranked advantage in Peterson \& Dant (1990). Withane (1991) and Stanworth and Kaufmann (1996) listed 'support' (start-up and on-going support) - a more general attribute of which training may be a part of - fourth and fifth, respectively. Finally, 'lower risk' is ranked fifth in our study, second in Whitane (1991), and fourth in Stanworth and Kaufmann (1996).

\section{CONCLUSIONS}

The general conclusion of this study is that the motivation to become a franchisee moves around three clear advantages of the franchise system compared to an independent business: 1) using a trade name which gives the franchisee the advantage of being part of a brand known in the market, 2) working with a business format that has proven to be successful in other locations, and 3) the training provided by the franchisor to the franchisee to learn how to run the business and benefit from the processes and routines developed by the franchisor. The perception of 
lower risk of failure associated with the franchise option is another agreed upon reason, but it is probably a consequence of using a known trade name, a proven business format, and the training and support the franchisor gives to the franchisee.

In the hotel industry, the reasons to become a franchisee are the same. Mr. Joe Lavin stated his experience with the Marriott and Choice franchisees as, "Franchisees came to us looking for marketing, which is basically what the franchisee gets from the franchisor. The franchisee is buying the right to use a brand that has the potential to attract customers to the hotel, along with all the marketing assets associated with that brand: the reservation system, the customer loyalty program, the online sales, ... ; it is all marketing."

Mr. Jordi Frigola, Senior Vice President Jones Lang LaSalle Hotels in Europe and owner of an independent hotel in Barcelona (Spain), stated that his decision of not taking a franchised brand for his new hotel again highlights the importance of 'brand' in the potential franchisee's decision. "The brands that were available were not so attractive; their level of brand awareness was low and not clearly positioned; (...); having a franchised contract has a cost and would not give me additional sales; (...); having a franchised contract will also limit my future possibilities; (...); so I decided to go independent."

As we have seen with this theory and practice review, much remains to be studied about the motivations of franchisees in the hospitality industry, but we hope that with this synthesis, we have contributed to bringing some light to this interesting research topic.

\section{AUTHOR INFORMATION}

Ramón Diaz-Bernardo. An expert in strategic marketing, some years ago Professor Ramón Diaz-Bernardo decided to extend his field of research to tourism and hotel marketing strategy. Professor Diaz-Bernardo holds a degree in Engineering from Universidad de Oviedo (Spain), an MBA from ESDEN Business School (Madrid), and he is a Doctor in Business Administration (Ph.D.) from IESE Business School (Barcelona).

He is an active member of the Academy of Marketing and the American Marketing Association, where he is a regular contributor at their annual meetings. Furthermore, he is a visiting professor at Cornell University (U.S.A.), Nanyang Business School (Singapore), and Reykjavik University (Iceland), among other international business schools.

\section{REFERENCES}

1. Fulop C. and Forward, J. (1997), "Insights into Franchising: A Review of Empirical and Theoretical Perspectives", The Services Industries Journal, Vol. 17, No. 4

2. Izraeli, D. (1972), Franchising and the Total Distribution System, London: Longman

3. Knight, R. M., (1986), "Franchising From the Franchisor and Franchisee Points of View", Journal of Small Business Management, (July), pp. 8-15

4. Parsa, H.G. (1996), "Franchisor-Franchisee Relationship in Quick-Service-Restaurant Systems," Cornell Hotel and Restaurant Administration Quarterly, Vol. 37 (3), pp. $42-50$

5. Peterson, A. and. Dant, R. P (1990), "Perceived Advantages of the Franchise Option from the Franchisee Perspective: Empirical Insights from a Service Franchise”, Journal of Small Business Management, Vol. 28, pp. 46-61

6. Stanworth, J., and P. Kaufmann (1996), "Similarities and Differences un UK and U.S. Franchise Data: Towards a Dynamic Model of Franchise Motivation”, International Small Business Journal, Vol. 14, pp. $57-70$

7. Withane, S., (1991), "Franchising and Franchisee Behavior: An Examination of Opinions, Personal Characteristics, and Motives of Canadian Franchisee Entrepreneurs", Journal of Small Business Management, (January), pp. 22-29 